\title{
PENERAPAN METODE CIRCUIT TRAINING PADA MATERI LARI, LEMPAR DAN LOMPAT DI KELAS V SDN 2 CANGKOAK
}

\author{
Agus Didi Heryadi \\ SDN Cangkoak II Cirebon, Indonesia \\ heryadi.ag@gmail.com
}

\begin{abstract}
The problem in this study is the difficulty experienced by students in carrying out practice exercises. Circuit training method is considered as one way to overcome this problem. This study aims to improve the ability of Class $\mathrm{V}$ students in carrying out practice exercises using the Circuit Training method. The method used is Classroom Action Research with two cycles. The results obtained by the ability of students in class $\mathrm{V}$ in practicing the subject movements of Running, Throwing and Jumping increased by using the Circuit Training method. By using the Circuit Training method the activity of students from cycle to cycle increases.
\end{abstract}

Keywords: circuit training, physical education.

\section{ABSTRAK}

Masalah dalam penelitian ini kesulitan yang dialami siswa dalam melaksanakan praktek latihan. Metode circuit training dianggap sebagai salah satu cara untuk mengatasi masalah tersebut. Penelitian ini bertujuan untuk meningkatkan kemampuan siswa Kelas V dalam melaksanakan praktek latihan dengan menggunakan metode Latihan Sirkuit (Circuit Training). Metode yang digunakan adalah Penelitian Tindakan Kelas dengan dua siklus. Hasil penelitian diperoleh Kemampuan siswa kelas V dalam mempraktekkan gerakan-gerakan pokok bahasan Lari, Lempar dan Lompat meningkat dengan menggunakan metode Latihan Sirkuit (Circuit Training). Dengan menggunakan metode Latihan Sirkuit (Circuit Training) aktivitas siswa dari siklus ke siklus berikutnya mengalami peningkatan.

Kata Kunci: circuit training, pembelajaran penjas.

Submitted Feb 22, 2020 | Revised Mar 20, 2020 | Accepted Mar 22, 2020

\section{Pendahuluan}

Olahraga adalah serangkaian gerak raga yang teratur dan terencana untuk memelihara gerak (mempertahankan hidup) dan meningkatkan kemampuan gerak (meningkatkan kualitas hidup) (Subadiman, 2013). Olahraga merupakan kebutuhan hidup yang sifatnya periodik; artinya Olahraga sebagai alat untuk memelihara dan membina kesehatan, tidak dapat ditinggalkan. Olahraga merupakan alat untuk merangsang pertumbuhan dan perkembangan jasmani, rohani dan sosial. Struktur anatomis-anthropometris dan fungsi fisiologisnya, stabilitas emosional dan kecerdasan intelektualnya maupun kemampuannya bersosialisasi dengan lingkungannya nyata lebih unggul pada siswa-siswa yang aktif mengikuti kegiatan Penjas-Or dari pada siswa-siswa yang tidak aktif mengikuti Penjas-Or.

Dengan berdasarkan pemikiran di atas maka prestasi belajar penjas perlu adanya penataan dari berbagai segi antara lain dalam kaitannya dengan pengetahuan dasar siswa, cara belajar siswa dan juga kesiapan yang bersangkutan sebelum mengikuti suatu pelajaran. Pendidikan Jasmani (Penjas) adalah salah satu mata pelajaran yang banyak menerapkan 
pembelajaran di luar ruangan (outdoor), bahkan merupakan mata pelajaran yang dirasa sebagai wahana menyegarkan pikiran kembali (refreshing) setelah mendapatkan mata pelajaran didalam kelas (Permatasari dan Kartiko, 2019).

Salah satu prinsip pembelajaran Penjas adalah siswa merasa senang (Parlindungan, 2017). Guru harus menciptakan suasana yang menyenangkan dan memicu antusias siswa yang tentu saja telah disesuaikan dengan keadaan maupun sarana dan prasarana olahraga di sekolah. Guru harus mampu menentukan suatu strategi pembelajaran yang dapat merangsang aktivitas siswa dalam pelaksanaan pembelajaran. Dengan keterampilan tersebut, diharapkan guru mampu meningkatkan aktivitas siswa dalam pembelajaran Penjas karena akan berdampak pada keberhasilan siswa dalam mencapai tujuan pembelajaran. Di samping itu, siswa yang aktif dalam pembelajaran juga akan berdampak terhadap hasil belajar yang diperoleh.

Namun beberapa studi masih menunjukkan siswa belum aktif dalam pembelajaran penjas. Rendahnya ktivitas siswa dalam pembelajaran penjas juga terjadi pada beberapa siswa kelas V SD Negeri 2 Cangkoak Kecamatan Dukupuntang. Berdasarkan studi pendahuluan, ternyata beberapa siswa terlihat kurang aktif dalam mengikuti pelajaran pendidikan jasmani. Ada yang males-malesan, ada yang kurang serius dalam mengikuti pelajaran pendidikan jasmani, bahkan ada diantaranya dengan berbagai dalih berusaha untuk tidak mengikuti pelajaran pendidikan jasmani, akibatnya prestasi belajar rendah dan tidak mencapai ketuntasan yang ditentukan.

Dari permasalahan di atas, maka diperlukan suatu langkah sebagai soluasi dari permasalahan tersebut. Salah satu upaya yang dapat dilakukan adalah dengan menentukan model pembelajaran yang dapat membuat siswa semangat sehingga mendorong siswa aktif belajar. Salah satu metode pelatihan yang diduga dapat meningkatkan prestasi olehraga adalah metode pelatihan Sirkuti (Circuit Training). Beberapa studi yang telah dilakukan mengenai penerapan pelatihan sirkuit, diantaranya Ardika, dkk. (2015), Trisandy (2017), Romadhoni dkk. (2018), Satria (2018) memperoleh hasil berupa peningkatan prestasi belajar siswa dalam pembelajaran penjas.

Menurut Irawadi (Perdima, 2017) circuit training adalah suatu rangkaian latihan yang terdiri dari pos-pos didalamnya. Pada umumnya circuit training adalah metode latihan memutar atau rotasi dari satu tempat ketempat berikutnya atau dalam kata lain latihan yang terdiri dari beberapa pos yang memutar, namun juga dapat dikembangkan dalam proses pembelajaran. Menurut Utomo dan Lhisdiantoro (2017) ciri-ciri circuit training terdiri dari beberapa pos yang dilakukan secara melingkar. Dalam melakukan circuit training terdapat beberapa pengaturan antara lain adalah diperbolehkan memilih pos mana saja yang akan dijadikan pos pertama melakukan latihan kemudian berpindah secara melingkar sesuai instruksi hingga semua pos terselesaikan semua; terdapat waktu maksimal dalam menyelesaikan satu pos atau jumlah repetisi; dan melakukan pertimbangan sebelum melakukan circuit training mengenai bentuk latihan, urutan latihan dari mudah ke kompleks), waktu latihan dan waktu istirahat. Setiawan dkk (dalam Azizil Fikri 2017:95-96) Kunci utama dari circuit training adalah mampu menuntaskan latihan semua pos dalam waktu singkat.

Pelatihan sirkuit (Circuit Training) adalah program dengan berbagai jenis beban kerja yang dilakukan secara simultan dan terus menerus dengan diselingi istirahat pada pergantian jenis beban kerja tersebut. Program pelatihan ini sangat baik, karena dapat membentuk berbagai kondisi fisik secara serempak. Bentuk pelatihan sirkuit (Circuit Training) memiliki tiga 
karakteristik yaitu; 1). Meningkatkan kesegaran kardiorespirasi dan kesegaran otot. 2). Menerapkan prinsip tahanan progresif. 3). Memungkinkan banyak individu berlatih dalam waktu yang sama, didasarkan pada kemampuan tiap individu, dan memperoleh latihan maksimal dalam waktu pendek.

\section{Metode Penelitian}

Metode yang digunakan dalam penelitian ini merupakan Penelitian Tindakan kelas (PTK). PTK merupakan suatu penelitian yang mengangkat masalah-masalah aktual yang dihadapi oleh guru di lapangan. PTK adalah proses pengkajian masalah pembelajaran di dalam kelas melalui refleksi diri dalam upaya untuk memecahkan masalah tersebut dengan cara melakukan tindakan yang terencana dalam situasi nyata serta menganalisis setiap pengaruh dari perlakuan tersebut (Sanjaya, 2011: 26). Pendapat tersebut sesuai pendapat yang disampaikan oleh Kasbolah (2001: 15), bahwa Penelitian Tindakan Kelas merupakan penelitian tindakan dalam bidang pendidikan yang dilaksananakan dalam kawasan kelas dengan tujuan untuk memperbaiki dan atau meningkatkan kualitas pembelajaran.

Banyak model Penelitian Tindakan Kelas yang dapat diterapkan, tetapi dalam penelitian ini menggunakan model Kemmis dan McTaggart di mana dalam perencanaannya menggunakan siklus sistem spiral yang di dalamnya terdiri dari empat komponen, yaitu rencana, tindakan dan observasi serta refleksi (Sujati, 2000: 23).

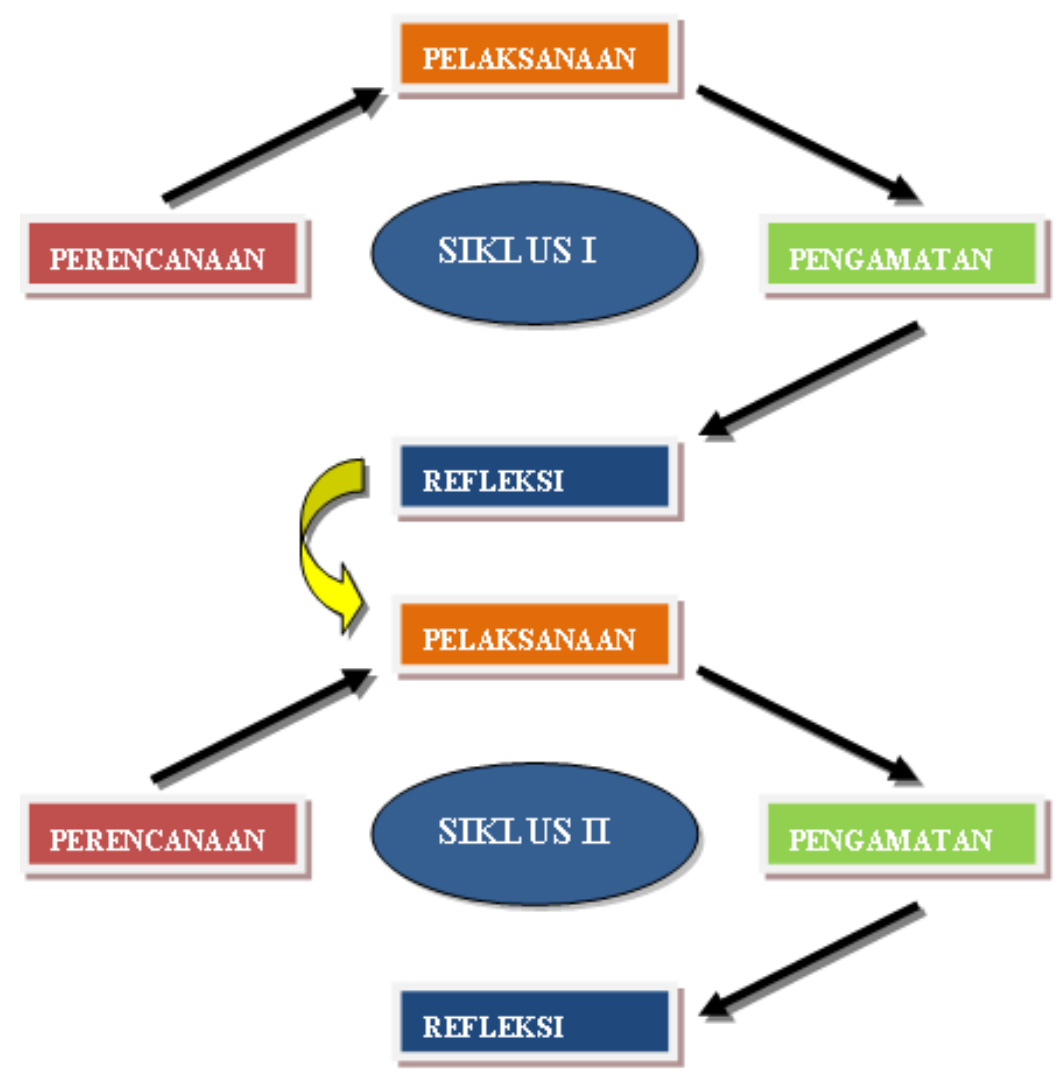

Gambar 1. Model kemmis dan Mc Taggart (Sujati, 2000: 23).

Subyek penelitian ini adalah siswa Kelas V SD Negeri 2 Cangkoak Kecamatan Dukupuntang Kabupaten Cirebon dengn jumlah siswa 40 anak. Dari nilai Pendidikan Jasmani 
dan Olahraga dan Kesehatan semester II, anak yang mendapat nilai $\geq 70$ sebesar $15 \%$ dan anak yang mendapat nilai $\leq 70$ sebesar $85 \%$. Lokasi Tindakan Kelas di kelas V SDN 2 Cangkoak Jalan Sawah Kalong No. 02 Kecamaan Dukupuntang Kabupaten Cirebon pada semester pertama tahun 2019/2020.

\section{Hasil dan Pembahasan}

Penelitian Tindakan Kelas (PTK) dilaksanakan di Kelas V SD Negeri 2 Cangkoak Kecamatan Dukupuntang Kabupaten Cirebon dan dilaksanakan pada bulan Agustus Oktober 2020. Sebelum dilakukan penelitian dilakukan pretest terhadap siswa untuk mengetahui kemampuan siswa terhadap materi yang akan diberikan. Penelitian ini dilaksanakan dalam 2 siklus. Setiap siklus terdiri atas tahap perencanaan,pelaksanaan tindakan, pengamatan dan refleksi.

Pada siklus 1, dimulai dengan perencanaan diantaranya masalah diidentifikasi dan dirumuskan, peneliti dan guru memilih secara selektif latihan praktek yang akan dikerjakan siswa dengan menggunakan metode Latihan Sirkuit (Circuit Training), menyiapkan pembelajaran dengan memberi tugas individu berupa latihan praktek yang harus diselesikan siswa dengan menggunakan langkah Sirkuit (Circuit Training), dan menyiapkan sarana untuk pencatatan kegiatan

Dalam kegiatan pelaksanaan pembelajaran, dimulai dengan Guru menjelaskan pembelajaran mata pelajaran Pendidikan Jasmani dan Olahraga dan Kesehatan kepada siswa dengan metode Latihan Sirkuit (Circuit Training) biasa. Sub pokok bahasan yang akan diajarkan adalah Lari, Lempar dan Lompat meliputi teknik lari cepat, latihan lompat jauh dan tolak peluru melalui latihan Sirkuit training (Circuit Training). Apersepsi yang dilakukan guru dengan metode praktek meliputi pola latihan Lari, Lempar dan Lompat dalam Pendidikan Jasmani dan Olahraga dan Kesehatan dan memberikan contoh praktek yang benar. Guru memberikan contoh latihan praktek yang penyelesaiannya menggunakan metode Latihan Sirkuit (Circuit Training) dan dikerjakan secara terbimbing bersama siswa dengan cara 1 loncat tali (skipping rope), pos 2; lari bolak-balik (settle run), pos 3; naik turun bangku swedia, pos 4; Zig-rag run, pos 5; loncat rintangan.dan Pos 6; squat trust. Selama mengerjakan praktek latihan, peneliti ikut mengawasi dan melihat proses dan hasil praktek siswa. Hal ini dilakukan agar benar-benar mengetahui bagaimana siswa mempraktekkan dan mengetahui kesalahan-kesalahan yang dilakukan siswa. Bimbingan dilakukan secara individu pada beberapa siswa yang masih kesulitan dalam mempraktekkan Lari, Lempar dan Lompat berlatih melalui sirkuit training. Latihan praktek dibahas dengan menunjuk siswa yang mempraktekan dengan benar untuk mempraktekkan Lari, Lempar dan Lompat. Selain itu dengan praktek guru mengungkap kembali hasil pekerjaan siswa tersebut untuk mengetahui pemahaman siswa. Pada akhir pembelajaran guru memberikan simpulan dengan metode Tanya jawab tentang penyelesaian praktek latihan dengan menggunakan metode Latihan Sirkuit (Circuit Training) serta guru memberikan tugas untuk berlatih lagi terhadap siswa.

Dalam kegiatan pengamatan, diperoleh hasil diantaranya yaitu Guru masih kaku dalam mengawali pelajaran dalam pembelajaran, Guru belum begitu mampu mengelola pembelajaran, Guru belum begitu mampu memberikan dorongan semangat ke siswa dalam mempraktekkan, 
sebagian besar siswa sudah paham terhadap tugas yang diberikan, tingkat kesalahan berbeda ada yang salah sedikit dan ada yang salah banyak.

Pada tahapan refleksi siklus I, berdasarkan hasil pengamatan diperoleh informasi bahwa dalam pengelolaan proses pembelajaran, guru belum begitu menguasai lapangan sehingga pembelajaran kurang lancar. Dalam menggunakan langkah Sirkuit (Circuit Training) ada beberapa siswa yang masih bingung dalam menjalankan langkah kedua yaitu menyusun rencana. Dengan demikian guru dianjurkan untuk menjelaskan dan memberi contoh kembali bagaimana mempraktekkan latihan kemudian mempraktekkan latihan dalam Pendidikan Jasmani dan Olahraga dan Kesehatan meliputi latihan leher, latihan otot. Ada beberapa siswa yang masih bingung dalam mempraktekkan latihan langkah yaitu memeriksa kembali. Oleh karena itu, guru dianjurkan untuk menjelaskan kembali langkah latihan kepada siswa. Masih ada beberapa siswa yang melakukan kesalahan pengoperasian dengan variabel. Siswa belum dapat menggunakan pola-pola latihan praktek dalam mempraktekkan latihan sehingga perlu ditekankan lagi penggunaan langkah kedua yaitu menyusun rencana.

Berdasarkan hasil tes siklus I diperoleh data anak yang mendapat nilai $\geq 70$ ada 60,00.\% dan yang masih mendapat nilai $<70$ ada 40,00\%. Secara garis besar, pelaksanaan siklus I berlangsung dengan baik dan kondusif akan tetapi kegiatan pada siklus I perlu di ulang agar kemampuan siswa dalam melaksanakan praktek latihan lari, lempar dan lompat dan dengan metode Latihan Sirkuit (Circuit Training) dapat ditingkatkan

Tabel 1. Data perhitungan test siklus I

\begin{tabular}{cccc}
\hline Jumlah Siswa & Nilai $\geq 70$ & Nilai $<70$ & Ketuntasan \\
\hline 40 & $24 \operatorname{anak}(60,00 \%)$ & 16 anak $(40,00 \%)$ & $60.00 \%$ \\
\hline
\end{tabular}

Berdasarkan lembar pengamatan siswa, dapat dilihat pada pelaksanaan penelitian siklus 1, kehadiran siswa 40 siswa (100\%), siswa yang melakukan tugas individu juga sudah semua siswa (40 siswa), siswa yang tidak sempurna melaksanakan praktek ada 16 siswa, yang masih kesulitan melaskanakan praktek ada 17 siswa dan siswa yang masih sama sekali tidak aktif ada 1 siswa. siswa yang dapat melaksanakan praktek 3 siswa, yang dapat mengajukan pertanyaan dan menjawab pertanyaan guru masing-masing ada 3 siswa. berdasarkaan hal tersebut peneliti menilai aktivitas siswa dalam kelas masih harus ditingkatkan.

Berdasarkan lembar observasi guru, pada umumnya hasilnya baik, hal ini dapat dilihat dari hasil penilaian dengan skor 4 namun untuk lebih mencapai hasil pembelajaran yang optimal masih perlu adanya peningkatan lagi.

Pada siklus II, dimulai dengan perencanaan diantaranya menyiapkan kembali pembelajaran berupa latihan praktek yang akan diselesaikan siswa dan menyiapkan lembar observasi, serta fasilitas lain.

Dalam pelaksanaan pembelajaran, guru menjelaskan pembelajaran mata pelajaran Pendidikan Jasmani dan Olahraga dan Kesehatan kepada siswa dengan metode Latihan Sirkuit (Circuit Training). Sub pokok bahasan yang akan diajarkan adalah Lari cepat, Lompat jauh dan Tolak peluru dalam praktek gerak dengan metode Latihan Sirkuit (Circuit Training). Apersepsi yang dilakukan guru dengan metode tanya jawab meliputi penyebutan gerakan-gerakan dalam Lari, Lempar dan Lompat. 
Guru memberikan contoh cara latihan praktek Lari, Lempar dan Lompat menggunakan metode Latihan Sirkuit (Circuit Training) dan dikerjakan secara terbimbing bersama siswa. Pemberian latihan praktek dengan berbagai variasi soal. Selama mengerjakan latihan praktek, peneliti ikut mengawasi dan melihat proses dan hasil pekerjaan siswa. Hal ini dilakukan agar benar-benar mengetahui bagaimana siswa menyelesaikan soal dan mengetahui kesalahankesalahan yang dilakukan siswa. Bimbingan dilakukan secara individu pada beberapa siswa yang masih kesulitan dalam mengerjakan. Evaluasi dibahas dengan menunjuk siswa yang menjawab dengan benar untuk melaksanakan latihan dan mengerjakan hasil pekerjaannya. Selain itu dengan Tanya jawab guru mengungkap kembali hasil pekerjaan siswa tersebut untuk mengetahui pemahaman siswa. Pada akhir pembelajaran guru memberikan simpulan dengan metode Tanya jawab tentang penyelesaian praktek latihan dengan menggunakan metode Latihan Sirkuit (Circuit Training) serta guru memberikan tugas untuk berlatihah kembali terhadap siswa. Setelah pembelajaran dilaksanakan dilakukan tes siklus I untuk mengetahui tingkat pemahaman siswa

Hasil pengamatan siklus II diperoleh hasil diantaranya secara garis besar guru sudah melakukan dan menerapkan pembelajaran metode Latihan Sirkuit (Circuit Training) dengan baik, tetapi hasilnya belum maksimal, hanya hasil yang diharapkan yang sudah tercapai. Suasana kelas tertib, terkendali dan kondusif. Dengan demikian proses pembahasan soal dapat berlangsung dengan baik. Siswa mulai terbiasa menggunakan langkah Sirkuit (Circuit Training) untuk mempraktekkan latihan menyajikan materi pembelajaran secara rinci dan menawarkan tingkat-tingkat kesulitan yang berbeda secara berurutan. Selama siswa melakukan tes, mengerjakan soal dengan tertib, tenang dan kondusif.

Pada tahapan refleksi siklus II, berdasarkan hasil pengamatan diperoleh informasi bahwa kesalahan siswa pada siklus I dapat dikurangi, faktor dari guru sudah baik dan faktor siswa sudah jauh lebih baik dari siklus I, hasil kerja siswa sudah meningkat, Latihan-latihan Praktek sudah dapat dikerjakan dengan metode Latihan Sirkuit (Circuit Training) dan tersusun secara urut dan sistematis, Berdasarkan hasil tes siklus II diperoleh data anak yang mendapat nilai $\geq$ 70 ada $92,5 \%$ dan yang masih mendapat nilai $<70$ ada $7,5 \%$.

Tabel 2. Data perhitungan test Siklus II

\begin{tabular}{cccc}
\hline Jumlah Siswa & Nilai $\geq 70$ & Nilai $<70$ & Ketuntasan \\
\hline 40 & 37 anak & 3 anak & $92.5 \%$ \\
& $(92,5 \%)$ & $(7,5 \%)$ & \\
\hline
\end{tabular}

Berdasarkan lembar pengamatan siswa, dapat dilihat pada pelaksanaan penelitian siklus 2, kehadiran siswa 40 siswa (100\%), siswa yang melakukan tugas individu juga sudah semua siswa (40 siswa), siswa yang tidak lengkap mengerjakan individu ada 6 siswa, yang masih kesulitan mengerjakan ada 5 siswa dan siswa yang masih sama sekali tidak aktif tida ada sehingga semua siswa sudah aktif. Sehingga dari aspek-aspek tersebut sudah dapat dikurangi dibanding pada siklus 1 sedangkan siswa yang dapat mengerjakan melaksanakan tugas latihan ada 2 siswa, yang dapat mengajukan pertanyaan dan menjawab pertanyaan guru masing-masing ada 5 dan 6 siswa. hal ini menunjukkan pada siklus 2 ini aspek-aspek tersebut sudah dapar ditingkatkan dibanding siklus 1 . Berdasarkan hal di atas peneliti menilai aktifitas siswa dalam kelas sudah baik dimana siswa sudah aktif dalam kegiatan pembelajaran. 
Berdasarkan lembar observasi guru, pada siklus 2 sudah baik,hal ini dapat dilihat dari skor penilaian yang diperoleh yaitu 4,27. Pada siklus 2 ini mengalami peningkatan jika dibandingkan dengan siklus 1 .

\section{Kesimpulan}

Kemampuan siswa kelas $\mathrm{V}$ dalam mempraktekkan gerakan-gerakan pokok bahasan Lari, Lempar dan Lompat dapat di tingkatkan dengan menggunakan metode Latihan Sirkuit (Circuit Training). Dengan menggunakan metode Latihan Sirkuit (Circuit Training) aktivitas siswa dari siklus ke siklus berikutnya mengalami peningkatan. Demikian juga KBM guru dari siklus ke siklus mengalami peningkatan yang lebih baik.

\section{Daftar Pustaka}

Ardika, IMY, dkk. (2015). Pengaruh Circuit Training Terhadap Kelincahan Dan Daya Ledak Otot Tungkai. Jurnal Ilmu Keolahragaan Undiksha, 3(1), 1-10

Fikri, A. (2017). Meningkatkan Kebugaran Jasmani Melalui Metode Latihan Sirkuit Dalam Pembelajaran Pendidikan Jasmani Olahraga Dan Kesehatan Di SMA Negeri 1 Lubuklingga. Jurnal Sportif, 3(1), 1, 89-102.

Kasbolah (2001). Penelitian Tindakan Kelas. Jakarta: Bumi Aksara.

Parlindungan, D.P. (2017). Pendekatan Kreatif Pendidikan Jasmani Dan Olahraga Untuk Peningkatan Kesehatan Dan Gaya Hidup Sehat. Holistika: Jurnal Ilmiah PGSD, 1(1), 1623.

Permatasari, DK, \& Kartiko, DC. (2019). Pengaruh Penerapan Metode Circuit Training Terhadap Hasil Belajar Dribble Bola Basket. Jurnal Pendidikan Olabraga dan Kesehatan, 7 (2), 283-286.

Perdima, Feby Elra. 2017. Pengaruh Metose Latihan Sirkuit, Metode Konvensional TerhadapKeterampilan Dasar Bola Basket. ALTIUS, 02(01), 9-14

Romadhoni, DL, dkk. (2018). Pengaruh Pemberian Circuit Training Terhadap Peningkatan Vo2 Max Pada Pemain Futsal Di Maleo Futsal Magetan. Jurnal Kesehatan, 11(1), 43-48.

Sanjaya. (2010). Penelitian Tindakan Sekolah. Jakarta: Kencana.

Satria, HM., (2018). Pengaruh Latihan Circuit Training Terhadap Peningkatan Daya Tahan Aerobik Pemain Sepakbola Universitas Bina Darma. Jurnal Ilmiah Bina Edukasi. 11(1), 36-48.

Sujati. (2000). Penelitian Tindaka Kelas. Yogyakarta. FIP. UNY.

Subadiman, B. (2013). Olahraga Kesehatan Tenaga Dalam. Jurnal Ilmu Keolabragaan, 12 (2), 2631.

Trisandy, M. (2017). Peningkatan V02 Max Melalui Latihan Circuit Training Pada Siswa Kelas VIII.4 SMP Negeri 4 Kota Bengkulu. KINESTETIK : Jurnal Ilmiah Pendidikan Jasmani, 1 (2), 70-85.

Utomo, AAB, \& Lhisdiantoro, G. (2017). Latihan Weight Training dengan Metode Circuit Training Terhadap Hyperthropy Otot. Prosiding Seminar Nasional Hasil Penelitian "Penguatan Kualitas Pendidikan Tinggi Melalui Publikasi Ilmiah Bereputasi", 335-341 